\title{
The Students' Satisfaction on the Performance of the FFS Faculty Members, A.Y. 2016
}

\author{
Dr. Romeo C. Castillo, Dr. Leovigildo Lito D. Mallillin
}

\author{
FFS lecturer Faculty of Foundation Studies Gulf College, Sultanate of Oman
}

\begin{abstract}
This study investigated the student's satisfaction on the academic performance of FFS lecturers for the S.Y. 2015-2016. The study sample consisted of twenty five (25) respondents purposively selected from the foundation department. A questionnaire was developed and administered on the respondents. The collected data were analyzed using simple percentages. The results show that students perception of the lecturers' performance, attitude to work and teaching skills has a significant relationship on the students' academic performance likewise $32 \%$ of the respondents made mentioned that the lecturers gave test that cover important lessons assigned to or taken up in the class which is described as satisfactory, seven (7) or $28 \%$ claimed to be satisfactory in terms of course outline while five (5) or $20 \%$ of the respondents said that both items 2 and 4 received poor descriptions. The most significant conclusion is that there is a need to improve the performance of the lecturers inside the classroom in terms of; 1.1. Presentation of the lesson in a logical and organized order, 1.2 Interaction and student involvement in classroom discussion and 1.3 Development of critical and analytical thinking. It is also very evident that the students are confused on the course outline of different subject. It is noted that modules applied by lecturers on one subject is similar to many subjects .Lessons presented do not demonstrate current trends and students have no access to new information.
\end{abstract}

\section{INTRODUCTION}

Satisfaction may be defined from physical psychological and physiological perspective (Allport 1966). We use to judge or evaluate people base on their attitudes and performance. They see satisfaction as the process by which people attack meaning too experiences. They explained that after people attend to certain stimuli in their sensory membrane, processing continuous with satisfaction. Satisfaction is critical because it influences the information that enters the working memory. Background knowledge in the form of schemes affects satisfaction and subsequent learning. (Glower et al. 1990). This is a process through which we attempt to understand other persons. Attempt to obtain information about the temporary causes of other's behavior. Attitude to teaching skills could be defined as a consistent tenderly to reach in a particular way often positively toward any matter. Academic performance is important because strongly influence social thought, the way an individual think about the process of social information (Eggen and Kauchak 2001). Teachers' attitudes are fundamental to effective teaching. A teacher must be interesting. That is the teacher must work hid students into a state of interest in what. The teacher is going to teach him that every other object of attention is banished from his mind. The teacher should also fill the students with devouring curiosity to know what the next steps in connection with the subjects. (Eggen \& Kauchock, 2001) identified a member of teacher's attitudes that will facilitate a caring and supportive classroom environment. These are enthusiasm, caring, firm, democratic practice to promote students responsibility, use time for lesson effectively, have established efficient routines and interact freely with students and providing motivations for the students. Finding on teachers' skills and academic performance established the ff. facts: Teachers characteristics such as personal teaching efficacy, modeling and enthusiasm, caring and high expectation, promote learners motivation. These characteristics are associated with increase in students' achievement. Learning occurs when teachers use instructional tome efficiently. Learning takes place with ease and faster under teachers that are well organized. The way teachers interact with students influences their motivation and attitudes toward school. How students' perceive their teachers' academic performance will be measured based on; Teaching Method, Curriculum, Grading System and Physical Facility. It is said that order and learning in classroom is also based on the teachers' possession of essential teaching skills. No one can teach something to someone without doing it in some particular way, and that way of teaching has significant effects on the entire teaching and learning situation. Teaching is a process of continuous personal development and professional self-discovery along side an emerging understanding of the teaching and learning process. (Ehiodew \& Ajibode 2000). If there is an art essential to good teaching, it is that of communication. It is very important because teaching cannot occur without the use of oral or sign language communications. It means that teachers should also monitor his/her own voice to ensure that the presentation is clear and logical. (Eggen and Kauchock, 2001) highlighted four aspects of effective communication that are highly essential for learning and 
communication. These are prescribed terminology, connected discourse, transition signals and emphasis. Good and effective teachers link ideas together at the end of the lesson. Receives previous works and help students' link what has been learnt to what is coming. Academic performance is the display of knowledge attained or skills developed in school subjects designated by test and examination scores or marks assigned by the subject teachers. Performance is individual interest potentials in terms of intelligence combined with other sociological factors. Teachers variable are also noted to have effect on students' academic performances. These include teachers' knowledge of subject matter, teaching skills, attitude in the classroom, teachers' qualification and teaching experience.

\section{STATEMENT OF THE PROBLEM}

1. What is the profile of the respondents in terms of gender?

2. Do lecturers of FFS applied the necessary teaching skills?

3. Do the lecturers of FFS demonstrate the desired knowledge based on the prescribed curriculum?

4. Do the lecturers of FFS use the correct grading system?

5. Are the students well provided by the needed materials like books, magazines and computers?

\section{SIGNIFICANCE OF THE STUDY}

This study is significant to the following sectors:

\section{Administrators}

It motivates the administrators to monitor the quality of teachers in Gulf College and provides basis for measuring such improvements. More importantly, monitoring the achievements of lecturers in terms of their teaching skills and methods of presenting lessons will be a clear evidence for quality education. It indicates whether the quality of schooling in one educational institution is getting better or worse from year to year.

Parents

This serves as the basis for conferences and meetings with parents on how to help the students improved academically.

\section{Lecturers}

To the lecturers, it also motivates them to monitor quality way carefully since the overall school results reflect their competence and efficiency.

Students

It can be used as a means of the needed facility necessary to improve their academic performance.

\section{DEFINITION OF TERMS}

1. Academic Performance - is the display of knowledge attained or skills developed in school subjects designated by the subject teachers. It could be said to be any expressions used to represent students in scholastic standing.

2. Students Satisfaction- any expression used to represent students 'scholastic standing based on the teachers' knowledge, skills attitudes and behavior inside the classroom using the prescribed technique and approaches in teaching.

3. Teachers - are categorized to have positive attitude and good personal qualities bolster students 'academic performance. They are the models inside and outside the classroom showing intelligence and proficiency and good rapport with the students making academic growth.

\section{CONCEPTUAL FRAMEWORK}

This study is adopting the view of the psychological concept of satisfaction as the way through which we evaluate teachers'. This will adopt the view of theoretical basis for students' satisfaction on the academic performance of teachers' knowledge of subject matter, attitude to work and teaching skills in GULF COLLEGE. In this study therefore, the students of GULF COLLEGE are serving as judges, judging their teachers' professional competence and their teaching effectiveness. Allport theory was found appropriate to be used as the theoretical basis for this study because of his explanation on the processes involved.

Common judgment - In evaluating a teacher there must always be special reason in view. The reasons' for this study is to determine whether students' evaluation of the selected teachers' variable will determine or correlate with the students' academic performance. (Allport 1991).

Categorization Tendency - Allport asserted that one of the most important things to do in perceiving any object is to place it in a familiar category. That is our first assignment is to place a person in the category of the generalized stipulated in literatures. Also the selected variables and students' academic performance belongs to familiar category in education psychology. 
Combining Cues - Allport claimed that judging people involves putting together many bits of information. This study therefore will determine the reliability of students' evaluation of teachers' knowledge attitude and teaching skills using a statistical measure of their responses with their academic performance.

\section{REVIEW OF RELATED LITERATURE}

Academic performance could be defined as the display of knowledge attained or skills developed in school subject designated by test and examinat6ion scores or marks assigned by the subject teachers .It could also be said to be any expressions used to represent students scholastic standing.For this reason and study students academic performances were based on the scholastic standings with reference to the performance of teachers inside the classroom. Teachers' knowledge is fully noted to have significant effects on students' academic performances. (Ehindero \& Ajbade, 1985). The consistence of this claims are asserted by Ford (1995).

Durojaiya, (1978) support the idea that teachers positive attitude and good personal qualities bolsters students academic performance. Aladejana (2000)asserted that students have preference for teachers who have competence in their subjects and who respects and trust students as individual, listen to ythe3ir problems understand their needs be patient with them and explain things in an interesting fashion.

Centra and Potter (1980) confirmed that teachers' attitudes are significantly related to students' academic growth or performance. Thus the result of this study will help find solution to the problems of students as well as the preparation of the teachers inside the classroom.

Potter (2001) has launched the largest program in the country to pay teachers performance based on how much academic progress students make from one year to the next. The program has attracted millions of dollars in support from the Brood Foundation and educational and government leaders all across America. Accordingly the program prospers because it attracts teachers to perform better. Academic achievement of students has improved at a faster rate than the other school who did adopt the program.

In many schools in Europe, performance pay was given to teachers.Teachers were awarded if the students performed well in , Math, English, ,communication skills, integrated project and computing .Research findings on teachers' performance (Brunning,1999) if there is an art essential to good teaching, it is that of proper teaching skills. It is important because academic performance of students is also measured .Skillful mentors find teaching habit forming, trying always to make the necessary improvement everyday. There are many teaching methods as there are teachers in the world. In teaching seven steps are the required skills maybe suggested for effective teaching. These are preparation for instruction presentation of the learning task correction of the trial response, fixation of response and test response. Even though the enumerated skills are interdependent, one is effective alone as it is combined with others. Eggen and Kauchak (2002) claimed that the interaction and integration of those skills are carried to the teaching and learning.

\section{METHODOLOGY}

This study comprised of lecturers of GULF COLLEGE for the S.Y. 2015-2016. Twenty five (25) respondents were chosen and answered questionnaires which focus on the teaching method, curriculum, grading system and the use of physical facility in reference to their satisfaction on the following areas. The selected sample were adjudged to how adequate exposure in the schools that could enable them to give valid responses to the questionnaire items.

\section{RESEARCH INSTRUMENT}

A questionnaire was used to collect data. This questionnaire was divided into four sections:

The first section contains item on the teaching method general pedagogy knowledge approaches, critical and analytical analysis. The second section contains item on curricular course outlines, trends and new information. The third item contains grading system, computation of grades and item analysis.

The fourth item contains physical facility, books and other reading materials and also the canteen and classrooms. The items were adopted from the students' responses to teacher academic performance. Mean frequency percentage were used to know the results of the four items presented in the questionnaire.

\section{ANALYSIS AND DISCUSSION}

1. What is the profile of the respondents in terms of gender?

Table 1.1

Frequency and Percentage Distribution of Respondents in terms of gender.

\begin{tabular}{|c|c|c|}
\hline Gender & Frequency & Percentage \\
\hline Male & 23 & 92 \\
Female & 2 & 8 \\
\hline Total & $\mathbf{2 5}$ & $\mathbf{1 0 0}$ \\
\hline
\end{tabular}


Table 1 shows that out of 25 respondents, 2 or $8 \%$ are female 23 or $92 \%$ are male. It also indicates that most of the respondents are male as reflected in the total which is 23 or $92 \%$.

2. Do teachers of GULF COLLEGE applied the necessary teaching skills?

Table 1.2Frequency and Percentage Distribution of Respondents on the Teaching Method

\begin{tabular}{|c|c|c|c|}
\hline Teaching Method & Frequency & Percentage & Description \\
\hline $\begin{array}{l}\text { 1. Do the lecturers present the lesson in logical } \\
\text { and organized order? }\end{array}$ & 6 & 4 & Satisfactory \\
\hline $\begin{array}{l}\text { 2. the lecturers consider students' } \\
\text { involvement and active interaction } \\
\text { throughout the period? }\end{array}$ & 10 & 40 & Poor \\
\hline $\begin{array}{l}\text { Do the lecturers enable students to develop } \\
\text { critical and analytical thinking? }\end{array}$ & 4 & 16 & Poor \\
\hline $\begin{array}{l}\text { 4. Do the lecturers fluent enough to use the } \\
\text { English language? }\end{array}$ & 5 & 20 & Satisfactory \\
\hline TOTAL & $\mathbf{2 5}$ & $\mathbf{1 0 0}$ & \\
\hline
\end{tabular}

The table shows that 10 or $40 \%$ of the respondents mentioned that the lecturers consider students involvement and active interaction throughout the period and described as poor. Six (6) or $24 \%$ of them said that they present the lesson in logical and organized order. Five (5) or 20\% described teachers' ability to use English language which is described as satisfactory, while four (4) or $16 \%$ that teachers have the ability to develop the critical and analytical thinking skills of the students.

This clearly implies that the lecturers seldom involve students in classroom interaction .Students are not given enough space in classroom discussion.

3. Do the lecturers of GULF COLLEGE demonstrate the desired knowledge based on the prescribed curriculum?

Table 1.3Frequency and Percentage Distribution of Respondents on Curriculum

\begin{tabular}{|l|l|l|l|}
\hline Curriculum & Frequency & Percentage & Description \\
\hline $\begin{array}{c}\text { 1. Do the lecturers demonstrate knowledge of the } \\
\text { lesson presented? }\end{array}$ & 7 & 28 & Satisfactory \\
\hline $\begin{array}{c}\text { 2. Is the course outline given and discussed at the } \\
\text { start of the term? }\end{array}$ & 5 & 20 & Satisfactory \\
\hline $\begin{array}{c}\text { 3 Do the lecturers give test that cover important } \\
\text { lessons assigned or taken up in the class?. }\end{array}$ & 8 & 32 & Satisfactory \\
\hline $\begin{array}{c}\text { 4. Does the lesson demonstrate current trends and } \\
\text { encourage students to keep up with the new } \\
\text { information? }\end{array}$ & 5 & 20 & Poor \\
\hline TOTAL & $\mathbf{2 5}$ & $\mathbf{1 0 0}$ & \\
\hline
\end{tabular}

The table shows that 8 or $32 \%$ of the respondents made mentioned that the lecturers gave test that cover important lessons assigned to or taken up in the class which is described as satisfactory. Seven (7) or 28\% claimed to be satisfactory in terms of course outline. While five (5) or $20 \%$ of the respondents said that both items 2 and 4 received poor descriptions.

This implies that the lecturers are not resourceful enough to keep abreast with the current trends and information.

4. Do the lecturers of GULF COLLEGE use the correct grading system?

Table 1.4Frequency and Percentage Distribution of Respondents on Grading System

\begin{tabular}{|l|l|l|l|}
\hline Grading System & Frequency & Percentage & Description \\
\hline $\begin{array}{l}\text { 1. Is the test given reflects the subject } \\
\text { matter in the curriculum? }\end{array}$ & 12 & 48 & Satisfactory \\
\hline $\begin{array}{l}\text { 2. Is the grading system used shows } \\
\text { fairness and impartiality? }\end{array}$ & 7 & 28 & Satisfactory \\
\hline $\begin{array}{l}\text { 3. Are the students oriented on the grading } \\
\text { system used by the institution? }\end{array}$ & 3 & 12 & Poor \\
\hline $\begin{array}{l}\text { 4. Do the lecturers explain to the students } \\
\text { how the grades are computed? }\end{array}$ & 3 & 12 & Poor \\
\hline
\end{tabular}


TOTAL 25

100

The table shows that 12 or $48 \%$ of the respondents made mentioned that the test given reflects the subject matter in the curriculum described as satisfactory. Seven (7) or $28 \%$ claimed that the grading system showed fairness and impartiality and described as satisfactory. Three (3) or $12 \%$ of the respondents said that both items 3 and received poor descriptions respectively. This implies that the students are not well oriented on the grading system and also not being informed on how grades are computed.

5. Are the students well provided by the needed materials like books, magazines and computers?

Table 1.5Frequency and Percentage Distribution of Respondents on Physical Facility

\begin{tabular}{|c|c|c|c|}
\hline Physical Facility & $\begin{array}{l}\text { Freque } \\
\text { ncy }\end{array}$ & $\begin{array}{l}\text { Percent } \\
\text { age }\end{array}$ & $\begin{array}{l}\text { Descriptio } \\
\text { n }\end{array}$ \\
\hline $\begin{array}{l}\text { 1. Does the library contain sufficient books } \\
\text { for the subjects? }\end{array}$ & 11 & 44 & Poor \\
\hline $\begin{array}{l}\text { 2. Is the classroom size sufficient to } \\
\text { accommodate class size? }\end{array}$ & 4 & 16 & $\begin{array}{l}\text { Satisfactor } \\
\mathrm{y}\end{array}$ \\
\hline $\begin{array}{l}\text { 3. Does the classroom have an atmosphere } \\
\text { conducive to learning ?. }\end{array}$ & 6 & 24 & Poor \\
\hline $\begin{array}{l}\text { 4. Is the canteen ambiance of good } \\
\text { sanitation and offers healthy food? }\end{array}$ & 3 & 12 & Poor \\
\hline TOTAL & 25 & 100 & \\
\hline
\end{tabular}

The table shows that 11 or $44 \%$ of the respondents said that the library contained sufficient books and other related materials like references which is described as poor. Four (4) or $16 \%$ of the respondents claimed that the classroom size is sufficient to accommodate class size and described as poor .Six (6) or 24\%of the students mentioned that there is a classroom atmosphere conducive to learning described as poor by the three or $12 \%$ of the respondents. This implies that the library materials are not sufficient enough to support the needs of the students. As shown from the results that the library is in need to subscribe reading materials like magazines, newspapers and journals and additional textbooks are also necessary as mentioned from the results.

\section{CONCLUSIONS}

1. The most significant conclusion is that there is a need to improve the performance of the lecturers inside the classroom in terms of;

1.1. Presentation of the lesson in a logical and organized order.

1.2 Interaction and student involvement in classroom discussion.

1.3 Development of critical and analytical thinking.

2. It is also very evident that the students are confused on the course outline of different subjects. It is noted that modules applied by lecturers on one subject is similar to many subjects. Lessons presented do not demonstrate current trends and students have no access to new information.

3. As shown on table 4, most of the students are not properly oriented on the grading system used by the institution. The respondents likewise claimed that most of the classrooms are not conducive to learning.

4. In terms of physical facility, it is evident as shown on table 5 that the library has no sufficient library materials like textbooks, references, journals, magazines ,computers where students are accessible to online studies.

\section{RECOMMENDATIONS}

1. This study has meaningful implications to lecturers and school administrators since this study provides useful hints on the evaluation, promotion and appointment of lecturers and their teaching output as perceived by the students who are direct recipients of the teachers professional competence or incompetence.

2. Since there is a significant relationship between the students' perception on the lecturers " performance as basis of their scholastic standing, it is highly recommended for lecturers to make an inventory of subject matters whenever possible to obtain the desired output from the students .

3. As shown from the findings that students academic performance respectively correlate on the lecturers' skills in presenting the lesson, it is also recommended that teachers must continue to undergo researches for academic growth and better performance in the future.

4.There should be a comprehensive review and inventory on the library materials. Additional textbooks and references are needed for these are indispensable for the academic performance of the students. 


\section{REFERENCES}

[1] Allport G.W. (2009), Pattern and Growth in Personality, London ;William Clowes and Sons ,Ltd.

[2] Glover J. Ronning R. (2011) Cognitive Psychology For Teachers. New York

[3] Eggen P. Kauchak D. (2010) Strategies For Teachers ;Teaching Content and Thinking Skills (4 ${ }^{\text {th }}$ ed) Needham Heights M. A. Allyn and Bacon

[4] Brunning R. Schraw ,G. Ronning R. (2011) Cognitive Psychology and Instruction(3 ${ }^{\text {rd }}$ ed.)Apper Saddle River N.J. Prentice Hall.

[5] Baron R.A. Byrne D.(2011)Social Psychology ( $8^{\text {th }}$ ed.) Boston ,Allyn, and Bacon.

[6] Ford D.S. (1985)Self Concept and Perception of School Atmosphere among Senior College Students J. Negro Educ. 